\title{
Water Use Efficiency of Durum Wheat (Triticum durum Desf) under Deficit Irrigation
}

\author{
Hatem Cheikh M'hamed ${ }^{1}$, Mourad Rezig ${ }^{2} \&$ Mbarek Ben Naceur ${ }^{1}$ \\ ${ }^{1}$ Institut National de la Recherche Agronomique de Tunisie, Rue Hédi Karray, Ariana, Tunisie \\ ${ }^{2}$ Institut National de Recherche en Génie Rural Eaux et Forêts, Tunisie, Rue Hédi Karray, Ariana, Tunisie \\ Correspondence: Hatem Cheikh M'hamed, Institut National de la Recherche Agronomique de Tunisie (INRAT), \\ Rue Hédi Elkarray, 2083 Ariana, Tunisie. Tel: 216-98-579-788. E-mail: hatemcheikh@yahoo.fr
}

\author{
Received: February 25, 2015 Accepted: May 25, 2015 Online Published: July 15, 2015 \\ doi: $10.5539 /$ jas.v7n8p238 \\ URL: http://dx.doi.org/10.5539/jas.v7n8p238
}

\begin{abstract}
Wheat production in semi-arid area of Tunisia is limited by low rainfall (200-400 mm year $\left.{ }^{-1}\right)$, and by the irregularity of the distribution of precipitation and intensification of drought during cropping season. Therefore, irrigation is proposed as alternative to improve production and to maximize water-use efficiency (WUE) of wheat. So, rational irrigation is important for increasing crop yields and decrease water use. The objective of this study was to investigate the effects of different irrigation levels on water consumption, water use efficiency of total dry matter and water use efficiency of grain yields. The study was conducted for three consecutive cropping seasons (2005-2008). Results showed thatthe daily water consumption was varied through phonological stage. In fact, the maximum water consumption was observed at anthesis and grain filling stages. The cumulative water consumption was decreased between $3 \%$ and $37 \%$ respectively, from D1 (100\% ETM) to D2 (70\% ETM) and From D1 to D4 (rainfed). The relationship between total dry matter (TDM) and water consumption (WC) was in linearly regression with a high correlation coefficient $\left(\mathrm{R}^{2}\right)$ witch varied from 0.89 to 0.99 . The water use efficiency of total dry matter (WUE-TDM) gradually decreased when irrigation levels increased. The highest, WUE-TDM $\left(3.24 \mathrm{~kg} / \mathrm{m}^{3}, 3.65 \mathrm{~kg} / \mathrm{m}^{3}\right.$ and $\left.2.82 \mathrm{~kg} / \mathrm{m}^{3}\right)$ was recorded under rainfed condition (D4 treatment), respectively for 2005-2006, 2006-2007 and 2007-2008. On the contrary, water use efficiency of grain yield (WUE-GY) increase considerably when irrigation levels increase. In the first year of experiment, no significant difference between treatments was observed. Therefore, the moderate irrigation (D2) recorded the highest WUE-GY $\left(1.63 \mathrm{~kg} / \mathrm{m}^{3}\right)$ in the second cropping season (2006-2007). In 2007-2008, D1 and D3 irrigations regimes recorded the highest WUE-GY, respectively $1.17 \mathrm{~kg} / \mathrm{m}^{3}$ and $1.11 \mathrm{~kg} / \mathrm{m}^{3}$. Deficit irrigation regimes (D2 and D3) were considered as rational irrigation levels to improve grain yield of wheat and to maximize WUE in the semi-arid area of Tunisia.
\end{abstract}

Keywords: durum wheat, water consumption, total dry matter, grain yield, water use efficiency

\section{Introduction}

Tunisia is located in North Africa, on the border of the Mediterranean. A big part of climate is semi-arid and arid, which is marked by hot summers, cold winters and low rainfall (200 to $400 \mathrm{~mm}^{-1} \mathrm{ear}^{-1}$ ) with a high variability (Radhouene, 2013). Tunisia is exposed to climate change impacts (Vicente-Serrano, 2006) and it was qualified as the hot spot for climate change (Giorgi, 2006). In the next few decades, water scarcity, will be one of the most critical problems facing North African countries and especially in Tunisia (Ashton, 2002).In semi-arid areas of Tunisia, cereal yields are subject to significant fluctuations, given the inter-annual variability of rainfall, in addition to seasonal water deficits that could rule, even during a wet year (Sakiss et al., 1994). The scarcity of water and the uneven distribution of precipitation across time and space in this area are a very serious problem especially in recent years due to climate change. Therefore, controlled irrigation are vital for increasing crop yields and decrease water use (Aase \& Pikul, 2000; Blum et al., 1991; Blum \& Johnson, 1993; Li et al., 2001; Jiusheng, 1998; Katerji et al., 1998; Recio et al., 1999). Several water-saving methods have been developed (Belder et al., 2004; Bouman et al., 2007), among which, deficit irrigation is among the best technology that is used to reduce water consumption, increase water use efficiency (WUE), and subsequent use of that water for more efficient wheat production. Several researches indicate that deficit irrigation increases the WUE of wheat, maize, and rice by 10 to 42\% (Kang et al., 2000; Li et al., 2004, 2010; Soundharajan \& Sudheer, 2009). Also, 
Gajri et al. (1997) and Huang et al. (2004) found that rational irrigation can significantly increase the grains yield. However, excessive irrigation led to a decrease of crop WUE and that effective deficit irrigation may result in higher production and WUE. Xue et al. (2006) showed that deficit irrigation increased WUE of wheat. Same results were reported by Zhang et al. (2005) and Rezgui (2014) which showed that WUE is higher under supplemental irrigation with $60 \%$ of maximum Evapotranspiration $\left(2.2 \mathrm{~kg}_{\text {grains }} \mathrm{m}^{-3}\right)$ compared to supplemental

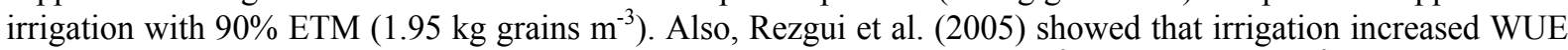
of Durum wheat in the semi-arid region of Tunisia from $0.86 \mathrm{~kg}_{\text {grains }} \mathrm{m}^{-3}$ to 1.24 grains $\mathrm{m}^{-3}$, respectively for rainfed and irrigation with $90 \%$ ETM. Olesen et al. (2000) showed that the effect of irrigation on wheat yield was almost solely due to increased transpiration, while WUE and harvest index remained unaffected. Kang et al. (2002) indicated that the responses of grain yield and WUE to irrigation varied considerably due to differences in soil water contents and irrigation schedules. Singh et al. (1991) concluded that the impact of limited irrigation and soil water deficit on crop yield or WUE depends on the particular growth stage of the crop. However, because deficit irrigation might reduce photosynthesis rate and accelerate leaf senescence if crop was over stressed, which in turn might cause decrease in wheat yield (Kobata et al., 1992; Wang, 2005).Comprehensive research was required to investigate the responses of durum wheat to deficit irrigation. So, the objective of our research was to investigate the effects of different levels of irrigation on water consumption, total dry matter and water use efficiency.

\section{Materials and Methods}

\subsection{Experimental Site}

The experiment was carried out at Bourbiaa/governorate of Ben Arouss, Tunisia $\left(36^{\circ} 37^{\prime} \mathrm{N}\right.$ Lat, $10^{\circ} 08^{\prime} 25^{\prime \prime} \mathrm{E}$ Long, $60 \mathrm{~m}$ asl), during three cropping seasons 2005/2006, 2006/2007 and 2007/2008. Bourbiaa region is characterized by semi-arid climate with $400 \mathrm{~mm}$ of the average annual rainfall. The soil had a clay texture with $180 \mathrm{~mm} \mathrm{~m}^{-1}$ total available water and $1.8 \mathrm{~g} \mathrm{l}^{-1}$ water salinity. The bulk density varies from 1.25 to 1.55 from the surface layer to the depth (Cheikh M'hamed et al., 2015).

\subsection{Plant Material}

One variety of Durum wheat "Triticum durum Desf", (Karim) was tested. The sowing was made with a drill on November $24^{\text {th }}$, November $31^{\text {th }}$, November $17^{\text {th }}$, respectively for 2005-2006, 2006-2007 and 2007-2008 cropping seasons. The sowing density was 350 grains $\mathrm{m}^{-1}$ (seed rate equal to $180 \mathrm{~kg} / \mathrm{ha}$ ) for the three years of experiments (Cheikh M'hamed et al., 2015).

\subsection{Experimental Design}

The experiment covered four treatments $\left(\mathrm{D}_{1}\right.$ : Full irrigated with 100\% ETM, D2: Deficit irrigation based on 70\% ETM, D3: Deficit irrigation based on 40\% ETM and D4: Rainfed with 0\% ETM). $100 \mathrm{~kg} \mathrm{~N} / \mathrm{ha}$ was applied at three phonological stages (30\% at 3 leafs stage, $40 \%$ at tillering stage and $30 \%$ at booting stage). The experimental design was Randomize Complete Blocking Design (RCBD) with 3 replications. Eight meters interval band was maintained between the water regimes treatments. Treatments descriptions are represented in the table below (Table 1). 
Table 1. Treatments descriptions

\begin{tabular}{llllll}
\hline Cropping season & Treatments & $\begin{array}{l}\text { Cropping season } \\
\text { rainfall }(\mathrm{mm})\end{array}$ & $\begin{array}{l}\text { Irrigation during } \\
\text { cropping season }(\mathrm{mm})\end{array}$ & ETC (mm) & ETR(mm) \\
\hline $2005-2006$ & D1 & 279 & 220 & 445 & 443 \\
& D2 & 279 & 160 & 445 & 434 \\
& D3 & 279 & 105 & 445 & 381 \\
& D4 & 279 & 0 & 445 & 306 \\
\hline $2006-2007$ & D1 & 347 & 190 & 516 & 479 \\
& D2 & 347 & 134 & 516 & 425 \\
& D3 & 347 & 76 & 516 & 373 \\
& D4 & 347 & 0 & 516 & 303 \\
\hline $2007-2008$ & D1 & 348 & 150 & 487 & 477 \\
& D2 & 348 & 114 & 487 & 464 \\
& D3 & 348 & 78 & 487 & 427 \\
& D4 & 348 & 0 & 487 & 380 \\
\hline
\end{tabular}

Note. ETC: crop evapotranspiration; ETR: real evapotranspiration or water consumption (WC).

\subsection{Field Measurements}

\subsubsection{Climatic Data}

Climate data were recorded daily by an automatic agrometeorological station. Collected data were minimum and maximum temperatures (Tmin and Tmax), minimum and maximum air relative humidity (HRmin and RHmax), wind speed (V) and rainfall (P) during the three growing seasons (2005/2006; 2006/2007 and 2007/2008). Reference evapotranspiration $\left(\mathrm{ET}_{0}\right)$ and solar radiation " $\mathrm{MJ} \mathrm{m}^{-2} \mathrm{~d}^{-1}$ " (Rs) were estimated by the CROPWAT software (FAO, version 8) using the FAO-Penman-Monteith approach (Allen et al., 1998).

\subsubsection{Total Dry Matter Production (TDM)}

The measurements of total dry matter $\left(\mathrm{g} \mathrm{m}^{-2}\right)$ were made by square meter. In 2005-2006, sampling wheat was collected at 45,70,99,118,138,164, 204 days after sowing (DAS). In 2006-2007, the sampling was achieved at 45, 67, 92, 114, 134, 164, 198 DAS. In 2007-2008, plants were collected at 45, 83, 104, 124, 140, 160, 211 DAS. All material collected was dried at $65^{\circ} \mathrm{C}$ to constant weight and dry weight was measured for each sampling. The weighing was done using a precision balance (Sartorius, Model PB3001).

\subsubsection{Grains Yield}

At maturity stage, the grains yield $\left(\mathrm{g} \mathrm{m}^{-2}\right)$ was made by square meter. The sampling at harvest was collected 204 days after sowing (DAS), 198 DAS and 211 DAS, respectively for 2005-2006, 2006-2007 and 2007-2008.

\subsubsection{Theoretical Formulations}

\section{1) Reference Evapotranspiration}

Weather data was used to calculate $\mathrm{ET}_{0}$. Climatic data used are maximum temperature (Tmax), minimum temperature (Tmin), humidity $(\mathrm{H})$, wind speed $(\mathrm{u} 2)$ and sunshine $(\mathrm{h})$ during three growing seasons (2005-2006, 2006-2007 and 2008-2009). Reference evapotranspiration ( $\left.\mathrm{ET}_{0}\right)$ was estimated by the CROPWAT software (FAO, version 8) using the FAO-Penman-Monteith approach (Allen et al., 1998).

\section{2) Water Consumption}

Water consumption is estimated with soil water balance equation as follows (Hillel, 1998):

$$
\mathrm{WC}=\mathrm{P}+\mathrm{I}+\mathrm{U}+\mathrm{R}-D w-\Delta S
$$

Where, $\mathrm{P}$ is the effective precipitation $(\mathrm{mm}), \mathrm{I}$ isthe irrigation $(\mathrm{mm}), \mathrm{U}$ is the upward capillary flow into the root zone $(\mathrm{mm}), \mathrm{R}$ is the runoff $(\mathrm{mm})$, D was the downward drainage out the root zone $(\mathrm{mm})$ and $\Delta S$ is the change of soil water stored in soil layer of 0-90 cm (mm). The upward and downward flow was estimated using Darcy's law (Kar et al., 2007; De Medeiros et al., 2005). Results indicated that the two items were insignificant at the experimental site. Runoff was also insignificant during the three growing seasons. Soil water content was measured each month with gravimetrically method. Soil water content data were collected for every $15 \mathrm{~cm}$ interval in soil depth. Some measurements were added before and after irrigation and heavy rain events. 
3) Water Use Efficiency

WUE of Total Dry Matter (WUE-TDM) and WUE of Grain yields (WUE-GY) was calculated using the following equation:

$$
\begin{gathered}
W U E-T D M\left(\mathrm{~kg} / \mathrm{m}^{3}\right)=\frac{T D M}{W C} \\
W U E-G Y\left(\mathrm{~kg} / \mathrm{m}^{3}\right)=\frac{G Y}{W C}
\end{gathered}
$$

Where, WUE is the water use efficiency $\left(\mathrm{kg} \mathrm{m}^{-3}\right)$, TDM is the total dry matter production $(\mathrm{kg})$, GY is the grain yields $(\mathrm{kg})$ and $\mathrm{WC}$ is the total water consumption over the whole growing season $(\mathrm{mm})$.

\subsection{Statistical Analysis}

An analysis of variance for all measured parameters was made, using Statistical Analysis System software (SAS, 1985). The variance analysis was completed by "multiple comparisons of means" with Newman Keuls test. Treatment means that the significant effects were separated by the test Least Significant Difference (LSD) at probability level of 5\% (Little \& Hill, 1978).

\section{Results}

\subsection{Water Consumption}

The evolution of daily water consumption (WC) at different water regimes (D1, D2, D3 and D4) for three cropping seasons (2005-2006, 2006-2007 and 2007-2008) are shown in Figure 1.

Results showed that the daily water consumption of Durum wheat was variable during cropping season and between years. Also, we observed that irrigation regimes (D1, D2, D3 and D4) was affected the daily water consumption of durum wheat during three cropping season (2005-2006, 2006-2007 and 2007-2008), especially during grain filling stage. For 2005-2006, the cumulative WC in D1 regime was $443 \mathrm{~mm}$ from sowing to harvest and the ETC was $445 \mathrm{~mm}$ (Figures 1a, 1d, 1g \& 1j). The cumulative WC recorded in D2 and D3 were respectively ( $434 \mathrm{~mm}$ and $381 \mathrm{~mm}$ ) and the deficit of water needs (WC compared to ETC) were $11 \mathrm{~mm}$ and 64 $\mathrm{mm}$ and were observed in the end of the season (from 160 DAS to 180 DAS), respectively for D2 and D3. However, for treatment D4 (rainfed), cumulative WC recorded was $306 \mathrm{~mm}$ and the deficit of water needs compared to ETC was $139 \mathrm{~mm}$ observed from 110 DAS to 180 DAS (anthesis and grain filling stages). In the second year of experiment (2006-2007), the cumulative WC recorded during the cropping season were $479 \mathrm{~mm}$, $425 \mathrm{~mm}, 373 \mathrm{~mm}$ and $303 \mathrm{~mm}$ respectively for D1, D2, D3 and D4. In fact, the deficits of water needs (cumulative WC compared to ETC witch is $516 \mathrm{~mm}$ ) were $37 \mathrm{~mm}, 91 \mathrm{~mm}, 143 \mathrm{~mm}$, and $213 \mathrm{~mm}$ respectively for D1, D2, D3 and D4. Theses gaps of water needs were observed during the grains filling stage from 165 DAS to 180 DAS for D1, from 140 DAS to 180 DAS for D2 and during anthesis and grains filling stages (from 110 DAS to 180 DAS) for treatments D3 and D4 (Figures $1 \mathrm{~b}, 1 \mathrm{e}, 1 \mathrm{~h} \& 1 \mathrm{k}$ ). For the last year of experiment (2007-2008), the cumulative WC recorded during the cropping season for treatments D1, D2, D3 and D4 were respectively $477 \mathrm{~mm}, 464 \mathrm{~mm}, 427 \mathrm{~mm}$ and $380 \mathrm{~mm}$. The ETC calculated was $487 \mathrm{~mm}$. Therefore, the deficit of water needs recorded were $10 \mathrm{~mm}$ for D1 observed in the end of the season from 180 DAS to 190 DAS and 23 $\mathrm{mm}, 60 \mathrm{~mm}$ and $107 \mathrm{~mm}$ respectively for treatments D2, D3 and D4 observed during the grains filling stage (Figures 1c, 1f, 1i \& 11). 


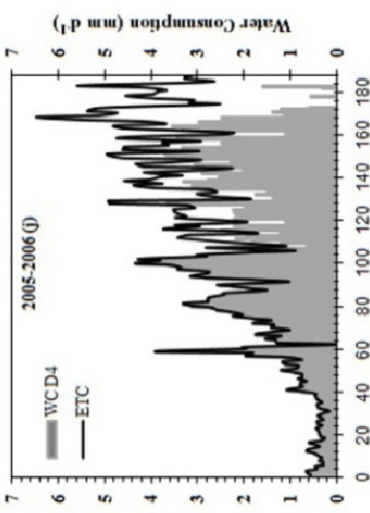

(, $\mathrm{p}$ шu) 5.1 .9

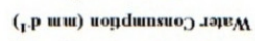

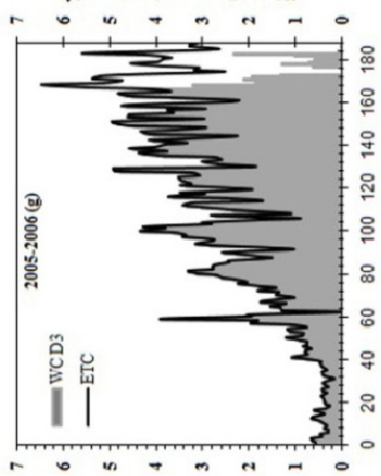

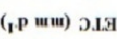

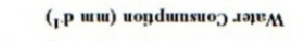

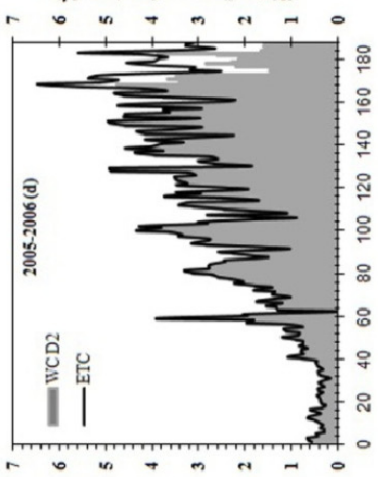

(,p แแ) ว.น.

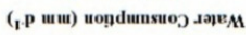

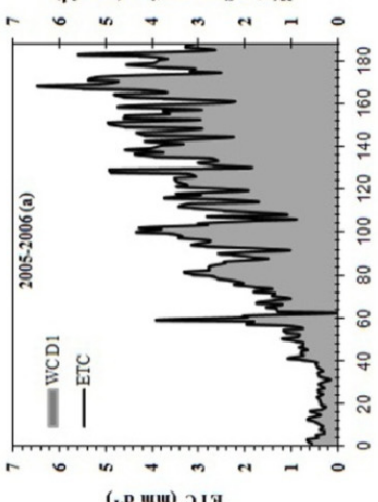

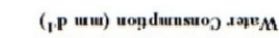

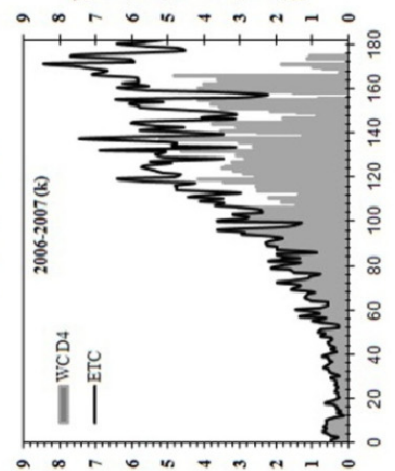

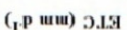

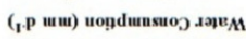

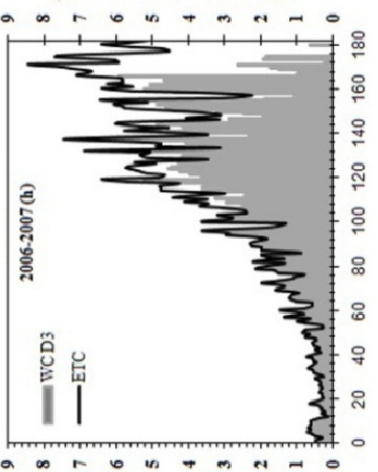

(1.P แm) ว.น.ร

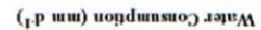

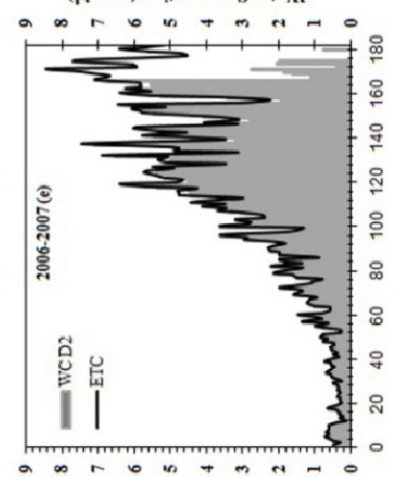

(1.P um) 0.1 .9

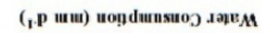

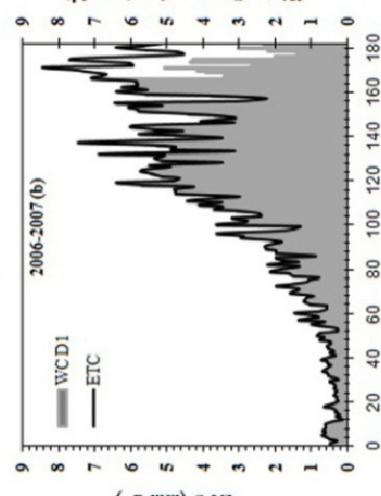

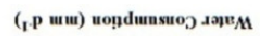

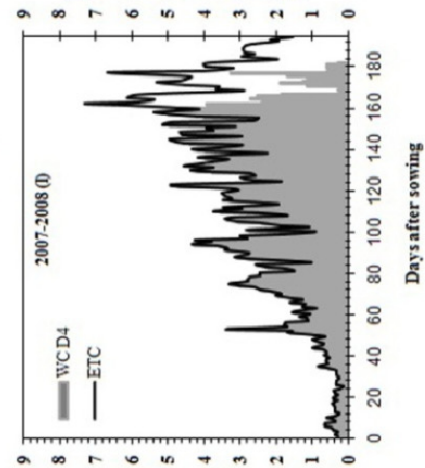

( p p w w) 9.19

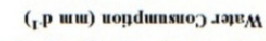

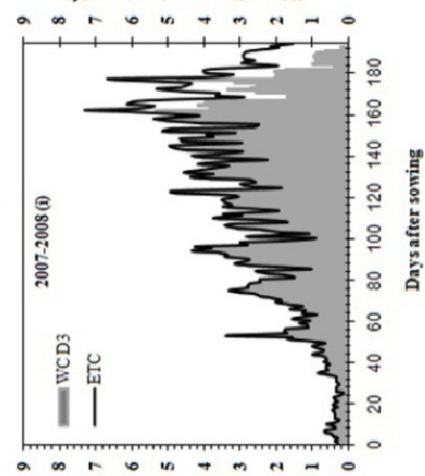

(, p w w) 0.1 .9

(I.P um) иор̣dunsuо

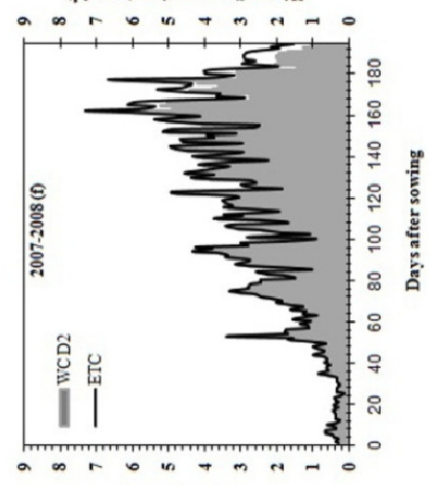

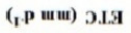

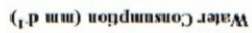

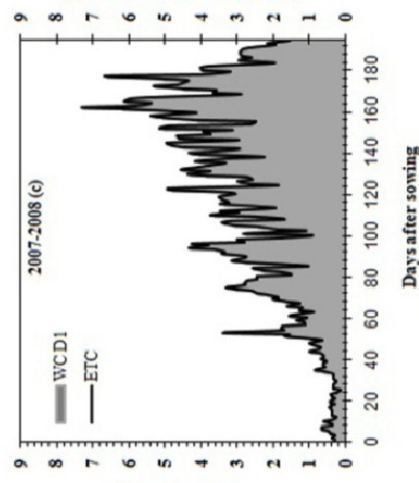

(,P w "11) ว.1.9

Figure 1. Daily water consumption ( $\mathrm{mm}$ ) of durum wheat for D1, D2, D3 and D4 water regimes during three cropping seasons (2005-2006, 2006-2007 and 2007-2008) 


\subsection{Water Use Efficiency}

\subsubsection{Water Use Efficiency from Sowing to Harvest}

The relationship between total dry matter accumulation and water consumption of wheat at various water regimes (D1, D2, D3 and D4) for three cropping seasons (2005-2006, 2006-2007 and 2007-2008) were shown in Figure 2.

Results showed that the relation between TDM and WC for three cropping seasons is linearly regression with a high correlation coefficient $\left(\mathrm{R}^{2}\right)$ witch varied from 0.89 to 0.99 . The slope of the linearly regression represent WUE $($ TDM $=$ WUE $\times$ WC). Our results showed that WUE presents a high variability according to treatments (D1, D2, D3 and D4) and between years (Figure 2). For the first experiment (2005-2006), the slope value varies from 2.61 to 2.78. In fact, the lowest slope value which represent WUE recorded under D3 treatment and the highest observed under D1, D2, and D4 treatments, respectively with 2.78, 2.73 and 2.74 (Figures 2a, 2d, 2g \& $2 \mathrm{j})$. However, in the second year of experiment (2006-2007), the WUE recorded under the four treatments are higher than the first year of experiment. The WUE was varied from 3.18 to 3.48. The highest WUE was recorded under D3 (3.47) and D4 (3.48) treatments and the lowest was observed for D1 (3.18) treatment (Figures 2b, 2e, $2 \mathrm{~h} \& 2 \mathrm{k}$ ). In the last year of experiment (2007-2008), the lowest WUE was observed for treatment D4 (2.83) and the highest was recorded under treatments D1, D3, respectively with 3.24 and 3.21 (Figures 2c, 2f, 2i \& 21).
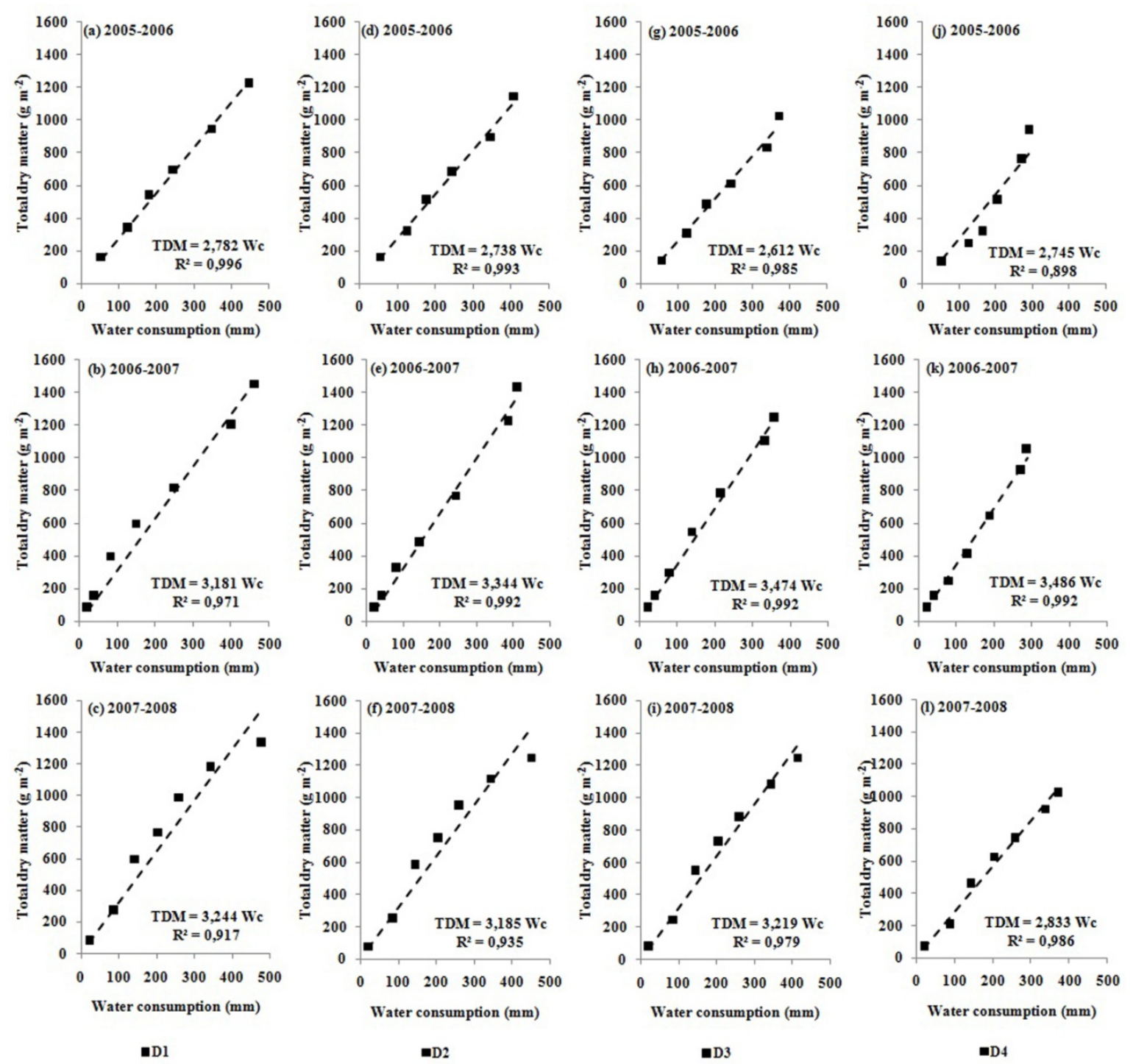

Figure 2. Relationship between Total Dray Matter and $\left(\mathrm{g} \mathrm{m}^{-2}\right)$ Water Consumption ( $\left.\mathrm{mm}\right)$, during the three experiments (2005-2006; 2006-2007 and 2007-2008), at four water regimes (D1, D2, D3 and D4) 


\subsubsection{Water Use Efficiency at Harvest}

The Water Use Efficiency of Total Dry Matter (WUE-TDM) and the Water Use Efficiency of Grain Yield (WUE-GY) at harvest under four water regimes (D1, D2, D3 and D4) were shown in Table 2.

Table 2. Water Use Efficiency $\left(\mathrm{kg} \mathrm{m}^{-3}\right)$ of Total Dry Matter (WUE-TDM) and Water Use Efficiency $\left(\mathrm{kg} \mathrm{m}^{-3}\right)$ of Grain Yield (WUE-GY) at harvest under four water regimes (D1, D2, D3 and D4), during three cropping seasons (2005-2006, 2006-2007 and 2007-2008)

\begin{tabular}{|c|c|c|c|c|c|c|}
\hline \multirow{3}{*}{ Treatments } & \multicolumn{6}{|c|}{ Cropping season } \\
\hline & \multicolumn{2}{|c|}{$2005-2006$} & \multicolumn{2}{|c|}{$2006-2007$} & \multicolumn{2}{|c|}{$2007-2008$} \\
\hline & WUE-TDM & WUE-GY & WUE-TDM & WUE-GY & WUE-TDM & WUE-GY \\
\hline D1 & $2.74 \mathrm{~b}$ & $1.18 \mathrm{a}$ & $3.13 \mathrm{c}$ & $1.46 \mathrm{c}$ & $2.78 \mathrm{ab}$ & $1.17 \mathrm{a}$ \\
\hline D2 & $2.81 \mathrm{~b}$ & $1.17 \mathrm{a}$ & $3.48 \mathrm{~b}$ & $1.63 \mathrm{a}$ & $2.55 \mathrm{~b}$ & $1.06 \mathrm{~b}$ \\
\hline D3 & $2.77 \mathrm{~b}$ & $1.13 \mathrm{a}$ & $3.48 \mathrm{~b}$ & $1.56 \mathrm{~b}$ & $2.96 \mathrm{a}$ & $1.11 \mathrm{ab}$ \\
\hline D4 & $3.24 \mathrm{a}$ & $1.20 \mathrm{a}$ & $3.65 \mathrm{a}$ & $1.28 \mathrm{~d}$ & $2.82 \mathrm{ab}$ & $1.08 \mathrm{~b}$ \\
\hline LSD & 0.17 & 0.07 & 0.053 & 0.017 & 0.293 & 0.067 \\
\hline Anova & $0.0012 * *$ & $0.2294 \mathrm{NS}$ & $0.0001 * * *$ & $0.0001 * * *$ & $0.041^{*}$ & $0.033^{*}$ \\
\hline
\end{tabular}

Note. LSD: Least Significant Difference; ${ }^{*}$ Significant difference at $5 \%$; $* *$ Significant difference at $1 \%$; $* *$ Significant difference at $0.1 \%$.

NS: No significant difference.

Statistical analysis shows that at harvest, the WUE-TDM was significantly $(\mathrm{P}<0.05)$ affected by water regimes (D1, D2, D3 and D4) for three cropping seasons (2005-2006, 2006-2007 and 2007-2008) (Table 2). However, no significant difference $(\mathrm{P}>0.05)$ was observed between D1, D2, D3 treatments for 2005-2006. The highest, WUE-TDM was recorded under treatment D4 $\left(3.24 \mathrm{~kg} \mathrm{~m}^{-3}\right.$ and $\left.3.65 \mathrm{~kg} \mathrm{~m}^{-3}\right)$, respectively for 2005-2006 and 2006-2007 (Table 2). For 2007-2008, the highest, WUE-TDM was obtained under D3 and D4 treatments, respectively with $2.92 \mathrm{~kg} \mathrm{~m}^{-3}$ and $2.82 \mathrm{~kg} \mathrm{~m}^{-3}$. Results show that WUE-TDM decrease when cumulative water consumption increase (Table 2). In fact, the lowest WUE-TDM $\left(2.74 \mathrm{~kg} \mathrm{~m}^{-3}\right.$ and $\left.3.13 \mathrm{~kg} \mathrm{~m}^{-3}\right)$ was obtained under D1 treatment, respectively for 2005-2006 and 2006-2007 and under D2 treatment $\left(2.55 \mathrm{~kg} \mathrm{~m}^{-3}\right)$ for 2007-2008 cropping season (Table 2). However for WUE-GY, ANOVA show no significant difference at $5 \%$ between water regimes (D1, D2, D3 and D4) in the first year of experiment (2005-2006). The WUE-GY varies from1.13 $\mathrm{kg} \mathrm{m}^{-3}$ (D3) to $1.20 \mathrm{~kg} \mathrm{~m}^{-3}$ (D4). For 2006-2007 and 2007-2008 cropping seasons, statistical analysis shows a significant difference between treatments (Table 2). The highest WUE-GY was recorded under moderate irrigation D2 $\left(1.63 \mathrm{~kg} \mathrm{~m}^{-3}\right)$ in 2006-2007 and under D1 $\left(1.17 \mathrm{~kg} \mathrm{~m}^{-3}\right)$ and D2 $\left(1.11 \mathrm{~kg} \mathrm{~m}^{-3}\right)$ in the last cropping season (2007-2008). However, the lowest WUE-GY $\left(1.28 \mathrm{~kg} \mathrm{~m}^{-3}\right.$ and $\left.1.08 \mathrm{~kg} \mathrm{~m}^{-3}\right)$ was obtained with treatment D4 (rainfed), respectively for 2006-2007 and 2007-2008 cropping seasons (Table 2).

\section{Discussion}

Irrigation is one of the important technologies controlling the yields of wheat crop. However, improper application of irrigation water may be detrimental to the productivity of the crop (Zwart \& Bastiaanssen, 2004; Sarkar, 2004). For example in eastern India, improper management of irrigation water is one of the reasons for the decline in yield of wheat crop in recent years. Deficit irrigation during plant growth stages that are relatively insensitive to water stress will increase the water use efficiency (Zhang et al., 1999).

The effects of four irrigation levels (D1, D2, D3 and D4) for Durum wheat on the daily water consumption (WC), water use efficiency of total dry matter (WUE-TDM) at harvest, water use efficiency of grain yields (WUE-GY) and on the relationship between water consumption and total dry matter were investigated. Total water consumptionis composed of three parts, namely, precipitation, irrigation and soil water supply but we mentioned that other factors such as genotypes transpiration and photosynthesis affect WC (Ya-Chen et al., 2006). Balwinder et al. (2011) showed that agriculture practice such as minimum tillage and no tillage improved the use efficiency of soil water and maintained better soil water storage during the growth stages of wheat compared with conventional tillage. Results showed a high variability of the daily water consumption through phonological stage of Durum wheat and between years witch characterized by variable annual rainfall and distribution. Also, 
we observed that irrigation regimes (D1, D2, D3 and D4) affected the daily water consumption and cumulative water consumption of Durum wheat during three cropping season (2005-2006, 2006-2007 and 2007-2008), especially during grain filling stage. However, from sowing to anthesis stages no difference between water regimes treatments was observed. This result may be attributed to high amount of rain recorded from sowing to anthesis stages. In fact, during these phonological stages Real Evapotranspiration (ETR) was particularly similar to maximum Evapotranspiration of Crop (ETC). Same results were observed by Guoyu (2007) in winter wheat which showed that for all the treatments tested, soil water content was high in the dormancy period (October-March) and gradually decreased in the fast growing period (March-June). In 2005-2006, the daily WC for all treatments tested is low in the first physiological stages (emergency, tilliring) and gradually decreased inthe fast growing period (anthesis and grain filling stage). The cumulative WC was decreased gradually from D1 to D4. The cumulative WC was $443 \mathrm{~mm}, 434 \mathrm{~mm}, 381 \mathrm{~mm}$ and $306 \mathrm{~mm}$, respectively for D1, D2, D3 and D4. Our results are in agreement with results observed by (Panda et al., 2003; Sun et al., 2006; Su et al., 2007). Theses authors recorded that limited irrigation or water deficit is conducive to reducing water consumption, which can improve WUE. Similarly trend of daily water consumption during phonological stage of wheat for all water regimes tested (D1, D2, D3 and D4) was observed during 2006-2007 and 2007-2008 cropping seasons. In 2006-2007, thedecrease of cumulative WC was $12 \%, 21 \%$ and $37 \%$, respectively from D1 to D2, from D1 to D3 and from D1 to D4. However, for 2007-2008 the decrease of cumulative WC was $3 \%, 11 \%$ and $21 \%$, respectively from D1 to D2, from D1 to D3 and from D1 to D4. These results were inagreement with those observed by Ya-Chen et al. (2006). The latter authors showed that the WC of genotypes tested were different according the soil water level studied. Some genotypes had more WC under soil water level 1 and other genotypes tested possessed higher WC under the condition of soil water level 2.

Although irrigation affects most of the functions of plant growth, this effect depends on the level of water regime, the length of time to which the plant is subjected to water stress. Results obtained showed, that from emergence to anthesis stages, a smalldifference of Total Dry Matter (TDM) between treatments was observed. In fact, the different irrigation levels (D1, D2 and D3) not severely affected the TDM during those phenological stages due to the high rainfall and the low irrigation doses. The relation between TDM and water Consumption (WC) for three cropping seasons is linearly regression with a high correlation coefficient $\left(\mathrm{R}^{2}\right)$ witch varied from 0.89 to 0.99. The slope of the linearly regression represent WUE (Figure 2). WUE was calculated to get an idea as to how effectively the irrigation water was used by the crop under different treatments during the three years experiments. Results obtained showed that WUE during cropping season (from sowing to harvest) presents a high variability according to treatments (D1, D2, D3 and D4) and between years. The highest value of slope was recorded under D1 (2.78), D4 (3.48) and D1 (3.24) treatments, respectively for 2005-2006, 2006-2007 and 2007-2008 cropping seasons. However, the lowest WUE was observed under D3 (2.61), D1 (3.18) and D4 (2.83) treatments, respectively for 2005-2006, 2006-2007 and 2007-2008 cropping seasons. At harvest, WUE was calculated and results showed thatWUE compared to TDM (WUE-TDM) was significantly affected $(\mathrm{P}<0.05)$ by water regimes (D1, D2, D3 and D4) for three cropping seasons (2005-2006, 2006-2007 and 2007-2008) (Table 2). However, no significant difference $(\mathrm{P}>0.05)$ was observed between D1, D2, D3 treatments for 2005-2006. The TDM-WUE gradually decreased when irrigation increased.The highest, WUE-TDM $\left(3.24 \mathrm{~kg} / \mathrm{m}^{3}\right.$, $3.65 \mathrm{~kg} / \mathrm{m}^{3}$ and $2.82 \mathrm{~kg} / \mathrm{m}^{3}$ ) was recorded under rainfed condition (D4 treatment), respectively for 2005-2006 and 2006-2007 and 2007-2008. However, the lowest WUE-TDM $\left(2.74 \mathrm{~kg} / \mathrm{m}^{3}, 3.13 \mathrm{~kg} / \mathrm{m}^{3}\right.$ and $\left.2.78 \mathrm{~kg} / \mathrm{m}^{3}\right)$ was obtained under D1 treatment (full irrigation), respectively for 2005-2006 and 2006-2007 and 2007-2008 cropping season (Table 2). This decrease on TDM-WUE probably due to the high annual rainfall for 3 cropping seasons and to the small increase on TDM compared to increasing on cumulative water consumption from D4 (rainfed) to D1 (full irrigation). These results were consistent with the findings of Hari Ram et al. (2013), who reported that WUE decreased with increasing irrigation level and it was higher in the I2 and I3 irrigation treatments compared with the I4 and I5 irrigation treatments. Maurya and Singh (2008) also reported a decrease in WUE with an increase in irrigation levels due to proportionately less increase in biomass with increase in water consumption. Similarly, Li et al. (2005) in the Loess Plateaurecorded that WUE decreased with increasing in irrigation and because grain yield did not increase linearly with irrigation, excessive irrigation even decreased grain production. Also, Singh et al. (1991) concluded that the impact of limited irrigation and soil water deficit on crop yield or WUE depends on the particular growth stage of the crop. However for WUE compared to grain yield (WUE-GY), ANOVA show no significant difference at 5\% between water regimes (D1, D2, D3 and D4) in the first year of experiment (2005-2006). The WUE-GY varies from $1.13 \mathrm{~kg} / \mathrm{m}^{3}$ to $1.20 \mathrm{~kg} / \mathrm{m}^{3}$. During 2006-2007 and 2007-2008 cropping seasons, statistical analysis shows a significant difference between treatments (D1, D2, D3 and D4), with increase in level of irrigation WUE-GY increased considerably due to increase in water use and grain yield under all the irrigation schedules. Our results were in agreement with Rezgui et al. (2005), who 
showed that irrigation increase WUE of Durum wheat in the semi-arid region of Tunisia from $0.86{\mathrm{~kg} g r a i n s ~ \mathrm{~m}^{-3}}^{-3}$ to 1.24 grains $\mathrm{m}^{-3}$, respectively for rainfed and irrigation with 90\% ETM. However in 2006-2007, WUE of the D2 irrigation $\left(1.63 \mathrm{~kg} / \mathrm{m}^{3}\right)$ schedule was comparatively higher than the D1, D3 and D4 irrigation schedules due to higher grain yield per unit useof water. A similar trend was observed during 2007-2008. In this year the higher WUE-GY recorded under D1 and D3 treatment $\left(1.17 \mathrm{~kg} / \mathrm{m}^{3}\right.$ and $\left.1.11 \mathrm{~kg} / \mathrm{m}^{3}\right)$ and the lowest WUE-GY $(1.08$ $\mathrm{kg} / \mathrm{m}^{3}$ ) was obtained with treatment D4 (Table 2). These findings are in line with those of Behera and Panda (2009), who observed that WUE of wheat under the I2 irrigation was higher than the I1 and I3 irrigation due to higher grain yield. Our results have been confirmed by many researchers (Gajri et al., 1997; Huang et al., 2004; Hong-Yong et al., 2006). They conclude that the rational irrigation can significantly increase the Jin et al. (1999) reported that excessive irrigation led to a decrease of crop WUE and that effective deficit irrigation may result in higher production and WUE. Also, Xue et al. (2006) showed that deficit irrigation increased WUE of wheat. Same results were reported by Zhang et al. (2005) and Rezgui (2014) which showed that WUE is higher under supplemental irrigation with $60 \%$ ETM $\left(2.2 \mathrm{~kg}_{\text {grains } \mathrm{m}^{-3}}\right)$ compared to supplemental irrigation with $90 \%$ ETM $\left(1.95 \mathrm{~kg}_{\text {grains }} \mathrm{m}^{-3}\right)$. On the contrary, Olesen et al. (2000) showed that the effect of irrigation on wheat yield was almost solely due to increased transpiration, while WUE and harvest index remained unaffected. Kang et al. (2002) indicated that the responses of grain yield and WUE to irrigation varied considerably due to differences in soil water contents and irrigation schedules. Singh et al. (1991) concluded that the impact of limited irrigation and soil water deficit on crop yield or WUE depends on the particular growth stage of the crop.

\section{Conclusion}

This study indicated that irrigation affect considerably the daily water consumption, cumulative water consumption, total dry matter, grain yield and WUE. However, this affect was variable between cropping seasons and treatments tested (D1, D2, D3 and D4 water regimes). The cumulativewater consumption increased gradually, with increasing irrigation levels. The relationship between total dry matter and water consumption was linearly regression with high correlation coefficient. WUE compared to TDM (WUE-TDM) of wheat decreased with increase of irrigation levels and the higher WUE-TDM was obtained under rainfed condition (D4). However, contrary result was recorded for WUE compared to grain yield (WUE-GY). The irrigation increase WUE-GY and the highest value was obtained under moderate irrigation. We concluded that moderate irrigation (D2) was recommended as optimal irrigation level in the semi-arid region of Tunisia for improving grain yield and WUE. More studies are needed to further establish the beneficial effects of deficit irrigation on growth, yields and WUE of durum wheat under different levels of nitrogen and for each phonological stage.

\section{References}

Aase, J. K., \& Pikul Jr., J. L. (2000). Water use in a modified summer fallow system on semiarid northern Great Plains. Agric. Water Manage., 43, 345-357. http://dx.doi.org/10.1016/j.agwat.2003.12.002

Allen, R. G., Pereira, L. S., Raes, D., \& Smith, M. (1998). Crop evapotranspiration: Guidelines for computing crop water requirements. FAO Irrigation and Drainage Paper 56, p. 300.

Ashton, P. J. (2002). Avoiding conflicts over Africa's water resources. Ambio, 31, 236-239. http://dx.doi.org/10.1579/0044-7447-31.3.236

Balwinder, S., Humphreys, E., Eberbach, P. L., Katupitiya, A., Yadvinder, S., \& Kukal, S. S. (2011). Growth, yield and water productivity of zero till wheat as affected by rice straw mulch and irrigation schedule. Field Crops Research, 121, 209-225. http://dx.doi.org/10.1016/j.fcr.2010.12.005

Behera, S. K., \& Panda, R. K. (2009). Integrated management of irrigation water and fertilizers for wheat crop using field experiments and simulation modeling. Agricultural Water Management, 96, 1532-1540. http://dx.doi.org/10.1371/journal.pone.0086938

Belder, P., Bouman, B. A. M., Spiertz, J. H. J., Cabangon, R., Guoan, L., Quilang, E. J. P., ... Tuong, T. P. (2004). Effect of water and nitrogen management on water use and yield of irrigated rice. Agric. Water Manage., 65, 193-210. http://dx.doi.org/10.1016/j.agwat.2003.09.002

Blum, A., \& Johnson, J. W. (1993). Wheat cultivars respond differently to a drying top soil and a possible non hydraulic root signal. J. Exp. Bot., 44, 1149-1153. http://dx.doi.org/10.1093/jxb/44.7.1149

Blum, A., Johnson, J. W., Ramsaeur, E. L., \& Tollner, E. W. (1991). The effects of a drying top soil and a possible nonhydraulic root signals on wheat growth and yield. J. Exp. Bot., 42, 1225-1231. http://dx.doi.org/10.1093/jxb/42.10.1225

Bouman, B. A. M., Humphreys, E., Tuong, T. P., \& Barker, R. (2007). Rice and water. Advances in Agronomy, 92, 
187-237. http://dx.doi.org/10.1016/S0065-2113(04)92004-4

Cheikh M'hamed, H., Rezigue, M., \& Ben Naceur, M. (2015). Deficit Irrigation of Durum Wheat (Triticum durum Desf): Effects on Total Dry Matter Production, Light Interception and Radiation Use Efficiency Under Different Nitrogen Rates. Sustainable Agriculture Research, 4(1), 26-40. http://dx.doi.org/10.5539/sar.v4n1p26

De Medeiros, G. A., Arruda, F. B., \& Sakai, E. (2005). Crop coefficient for irrigation beans derived using three reference evaporation methods. Agric. For. Meteorol., 115, 135-143. http://dx.doi.org/10.1016/j.agrformet.2005.11.010

Gajri, P. R., Gill, K. S., \& Chaudhary, M. R. (1997). Irrigation of sunflower (Helianthus annuus) in relation to tillage and mulching. Agric. Water Manage., 34, 149-160. http://dx.doi.org/10.1016/S0378-3774(97)00009-7

Giorgi, F. (2006). Climate change hot-spots. Geophysical Resources Letters, 33, 707-715. http://dx.doi.org/10.1029/2006gl025734

Guoyu, Q., Liming, W., Xinhua, H., Xiying, Z., Suying, C., Jin, C., \& Yonghui, Y. (2008). Water use efficiency and evapotranspiration of winter wheat and its response to irrigation regime in the north China plain. Agricultural and Forest Meterology, 148, 1848-1859. http://dx.doi.org/10.1016/j.agrformet.2008.06.010

Hari, R., Vikas, D., Krishan, K. V., \& Harinderjit, K. (2013). Grain yield and water use efficiency of wheat (Triticum aestivum L.) in relation to irrigation levels and rice straw mulching in North West India. Agricultural Water Management, 128, 92-101. http://dx.doi.org/10.1016/j.agwat.2013.06.011

Hillel, D. (1998). Environmental Soil Physics. Academics Press, London.

Huang, Y., Chen, L., Fu, B., Huang, Z., \& Gong, J. (2004). The wheat yields and water-use efficiency in the Loess Plateau: straw mulch and irrigation effects. Agric. Water Manage., 67, 55-68.

Jin, M. G., Zhang, R. Q., \& Gao, Y. F. (1999). Temporal and spatial soil water management: A case study in the Heiloonggang region, PR China. Agric. Water Manage., 42, $173-187$. http://dx.doi.org/10.1016/S0378-3774(99)00039-6

Jiusheng, L. (1998). Modeling crop yield as affected by uniformity of sprinkler irrigation system. Agric. Water Manage., 38, 135-146. http://dx.doi.org/10.1016/S0378-3774(98)00055-9

Kang, S. Z., Shi, W. J., \& Zhang, J. H. (2000). An improved water-use efficiency for maize grown under regulated deficit irrigation in north China. Field Crops Res., 67, $207-214$. http://dx.doi.org/10.1016/j.agwat.2009.08.011

Kang, S. Z., Zhang, L., Liang, Y. L., Hu, X. T., Cai, H. J., \& Gu, B. J. (2002). Effects of limited irrigation on yield and water use efficiency of winter wheat in the Loess Plateau of China. Agric. Water Manage., 55, 203-216. http://dx.doi.org/10.1016/S0378-3774(01)00180-9

Kar, G., Kumar, A., \& Martha, M. (2007). Water use efficiency and crop coefficients of dry season oilseed crops. Agric. Water Manage., 87, 73-82. http://dx.doi.org 10.1016/j.agwat.2006.06.002

Katerji, N., Van Hoorn, J. W., \& Hamdy, A. (1998). Salinity and drought, a comparison of their effects on the relationship between yield and evaportranspiration. Agric. Water Manage., 36, 45-54. http://dx.doi.org/10.1016/S0378-3774(97)00049-8

Kobata, T., Palta, J. A., \& Turner, N. C. (1992). Rate of development of postanthesis water deficits and grain

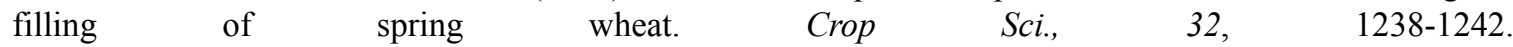
http://dx.doi.org/10.2135/cropsci1992.0011183X003200050035x

Li, F. M., Yan, X., Li, F. R., \& Guo, A. H. (2001). Effects of different water supply regimes on water use and yield performance of spring wheat in a simulated semiarid environment. Agric. Water Manage., 47, 25-35. http://dx.doi.org/10.1016/S0378-3774(00)00097-4

Li, F. S., Wei, C. H., Zhang, F. C., Zhang, J. H., Nong, M. L., \& Kang, S. Z. (2010). Water-use efficiency and physiological responses of maize under partial root-zone irrigation. Agric. Water Manage., 97, 1156-1164.

Li, J., Inanaga, S., Li, Z., \& Eneji, A. E. (2005). Optimazing irrigation scheduling for winter wheat in the north China plain. Agric. Water Manage., 76, 8-23. http://dx.doi.org/10.1016/j.agwat.2005.01.006

Li, W. L., Li, W. D., \& Li, Z. Z. (2004). Irrigation and fertilizer effects on water use and yield of spring wheat in semi-arid regions. Agricultural Water 
http://dx.doi.org/10.1016/j.agwat.2003.12.002

Little, T. M., \& Hills, F. J. (1978). Agricultural Experimentation: Design and Analysis (p. 350). John Wiley \& Sons. New York, USA.

Maurya, R. K., \& Singh, G. R. (2008). Effect of crop establishment methods and irrigation schedules on economics of wheat (Triticum aestivum) production moisture depletion pattern, consumptive use and crop water use efficiency. Indian Journal of Agricultural Sciences, 78, 830-833.

Olesen, J. E., Mortensen, J. V., Jorgensen, L. N., \& Andersen, M. N. (2000). Irrigation strategy, nitrogen application and fungicide control in winter wheat on a sandy soil. I. Yield, yield components and nitrogen uptake. J. Agric. Sci., 134, 1-11. http://dx.doi.org/10.1017/S0021859699007285

Panda, R. K., Behera, S. K., \& Kashyap, P. S. (2003). Effective management of irrigation water for wheat under stressed conditions. Agriculture Water $\quad$ Management, $\quad 63, \quad 37-56$. http://dx.doi.org/10.1016/S0378-3774(03)00099-4

Radhouene, L. (2013). Climate change impacts on North African countries and on some Tunisian economic sectors. Journal of Agriculture and Environment for International Development, 107(1), 101-113. http://dx.doi.org/10.12895/jaeid.20131.123

Recio, B., Rubio, F., Lomban, J., \& Ibanez, J. (1999). An econometric irrigated crop allocation model for analyzing the impact of water restriction policies. Agric. Water Manage., 42, 47-63. http://dx.doi.org/10.1016/S0378-3774(99)00030-X

Rezgui, M. (2014). Irrigation de complément et efficience de l'utilisation de l'eau de quelques variétés de blé dur cultivées en Tunisie. Journée Nationale sur la valorisation des Résultats de la Recherche dans le Domaine des Grandes Cultures. Tunis, le 17 avril 2014.

Rezgui, M., Zairii A., Bizid, E., \& Ben Mechlia, N. (2005). Consommation et efficacité d'utilisation de l'eau chez le blé dur (Triticum durum Desf.) cultivé en conditions pluviales et irriguées en Tunisie. Cahiers Agricultures, 14(4), 391-397.

Sakiss, N., Ennabli, N., Slimani, M. S., \& Baccour, H. (1994). La pluviométrie en Tunisie a-t-elle changé depuis 2000 ans: Recherche de tendances et de cycles dans les séries pluviométriques (p. 283). Institut National de la Météorologie (INM), Institut National Agronomique de Tunis (INAT) \& Agence Nationale de Protection de l'Environnement (ANPE), Tunis.

Sarkar, R. (2004). Assessment of sustainability of rice-wheat system under different combinations of tillage, crop residue and fertilizer nitrogen applications by crop simulation model (Ph.D. Thesis). Indian Institute of Technology, Kharagpur, India.

SAS Institute. (1985). SAS user's guide: Statistics. Version 6.0.SAS Inst. Inc., Cary, NC. USA.

Singh, P. K., Mishra, A. K., \& Imtiyaz, M. (1991). Moisture stress and the water use efficiency of mustard. Agric. Water Manage., 20, 245-253. http://dx.doi.org/10.1016/0378-3774(91)90021-A

Soundharajan, B., \& Sudheer, K. P. (2009). Deficit irrigation management for rice using crop growth simulation model in an optimization framework. Paddy Water Environ., 7, $135-149$. http://dx.doi.org/10.1007/s10333-009-0156-z

Su, Z. Y., Zhang, J. S., Wu, W. L., Cai, D. X., Lu, J. J., Jiang, G. H., ... Gabriels, D. (2007). Effects of conservation tillage practices on winter wheat water-use efficiency and crop yield on the Loess Plateau, China. Agric. Water Manage., 87, 307-314. http://dx.doi.org/10.1016/j.agwat.2006.08.005

Sun, H. Y., Liu, C. M., Zhang, X. Y., Shen, Y. J., \& Zhang, Y. Q. (2006). Effects of irrigation on water balance, yield and WUE of winter wheat in the north China plain. Agric. Water Manage., 85, 211-218. http://dx.doi.org/10.1016/j.agwat.2006.04.008

Vicente-Serrano, S. M. (2006). Spatial and temporal analysis of droughts in the Iberian Peninsula (1910-2000). Hydrol. Sci. J., 51(1), 83-97. http://dx.doi.org/10.1623/hysj.51.1.83

Wang, L., Qiu, G. Y., Zhang, X., \& Chen, S. (2005). Application of a new method to evaluate crop water stress index. Irrig. Sci., 24, 49-54. http://dx.doi.org/10.1007/s00271-005-0007-7

Xu, Z. Z., Yu, Z. W., \& Wang, D. (2006). Nitrogen translocation in wheat plants under soil water deficit. Plant Soil, 280, 291-303. http://dx.doi.org/10.1007/s11104-005-3276-2

Xue, Q., Zhu, Z., Musick, J. T., Stewart, B. A., \& Dusek, D. A. (2006). Physiological mechanisms contributing to 
the increased water-use efficiency in winter wheat under deficit irrigation. J. Plant Physiol., 163, 154-164. http://dx.doi.org/10.1016/j.jplph.2005.04.026

Ya-Chen, H., Hong-Bo, S., Li-Ye, C., \& Wu, G. (2006). Relationship between water use efficiency (WUE) and production of different wheat genotypes at soil water deficit. Colloids and Surfaces B: Biointerfaces, 53, 271-277. http://dx.doi.org/10.1016/j.colsurfb.2006.10.002

Zhang, H., Wang, X., You, M., \& Liu, C. (1999). Water-yield relations and water-use efficiency of winter wheat in the north China plain. Irrig. Sci., 19, 37-45. http://dx.doi.org/10.1007/s002710050069

Zhang, X., Chen, S., Liu, M., Pei, D., \& Sun, H. (2005). Improved water use efficiency associated with cultivars and agronomic management in the north China plain. Agron. J., 97, 783-790. http://dx.doi.org/10.2134/agronj2004.0194

Zwart, S. J., \& Bastiaanssen, W. G. M. (2004). Review of measured crop water productivity values for irrigated wheat, rice, cotton and maize. Agricultural Water Management, 69, 115-133. http://dx.doi.org/10.1016/j.agwat.2004.04.007

\section{Copyrights}

Copyright for this article is retained by the author(s), with first publication rights granted to the journal.

This is an open-access article distributed under the terms and conditions of the Creative Commons Attribution license (http://creativecommons.org/licenses/by/3.0/). 